OPEN ACCESS

Edited by:

Won-Gyu Choi,

University of Nevada, Reno,

United States

Reviewed by:

Yong Hun Chi,

Independent Researcher, Sejong,

South Korea

Renu Srivastava,

lowa State University, United States

*Correspondence:

Prem L. Bhalla

premlb@unimelb.edu.au

Specialty section:

This article was submitted to

Plant Abiotic Stress,

a section of the journal

Frontiers in Plant Science

Received: 30 January 2021

Accepted: 15 March 2021

Published: 14 April 2021

Citation:

Singh MB, Lohani N and

Bhalla PL (2021) The Role

of Endoplasmic Reticulum Stress

Response in Pollen Development

and Heat Stress Tolerance.

Front. Plant Sci. 12:661062.

doi: 10.3389/fp/s.2021.661062

\section{The Role of Endoplasmic Reticulum Stress Response in Pollen Development and Heat Stress Tolerance}

\author{
Mohan B. Singh, Neeta Lohani and Prem L. Bhalla* \\ Plant Molecular Biology and Biotechnology Laboratory, Faculty of Veterinary and Agricultural Sciences, The University
} of Melbourne, Parkville, VIC, Australia

Endoplasmic reticulum (ER) stress is defined by a protracted disruption in protein folding and accumulation of unfolded or misfolded proteins in the ER. This accumulation of unfolded proteins can result from excessive demands on the protein folding machinery triggered by environmental and cellular stresses such as nutrient deficiencies, oxidative stress, pathogens, and heat. The cell responds to ER stress by activating a protective pathway termed unfolded protein response (UPR), which comprises cellular mechanisms targeted to maintain cellular homeostasis by increasing the ER's protein folding capacity. The UPR is especially significant for plants as being sessile requires them to adapt to multiple environmental stresses. While multiple stresses trigger the UPR at the vegetative stage, it appears to be active constitutively in the anthers of unstressed plants. Transcriptome analysis reveals significant upregulation of ER stressrelated transcripts in diploid meiocytes and haploid microspores. Interestingly, several ER stress-related genes are specifically upregulated in the sperm cells. The analysis of gene knockout mutants in Arabidopsis has revealed that defects in ER stress response lead to the failure of normal pollen development and enhanced susceptibility of male gametophyte to heat stress conditions. In this mini-review, we provide an overview of the role of ER stress and UPR in pollen development and its protective roles in maintaining male fertility under heat stress conditions.

Keywords: endoplasmic reticulum stress, unfolded protein response, plant reproduction, pollen development, male gametophyte, heat stress, pollen, sperm cell

\section{INTRODUCTION}

The endoplasmic reticulum (ER) is a large, structurally complex organelle whose membrane can constitute half of a eukaryotic cell's total membranes. ER is a main production site for lipids and many proteins. Each cell carries two types of the ER: smooth ER (SER) and rough ER (RER). The SER is a site of lipid and sterol biosynthesis. In contrast, RER with its outer cytosol-facing surface studded with ribosome plays a crucial role in biosynthesis and productive post-translational processing and folding of secretory and transmembrane proteins. Nearly onethird of protein production and folding occurs in this organelle (Schubert et al., 2000). This highly active process requires finely tuned regulation of ER homeostasis. The protein homeostasis in the 
ER is maintained by chaperone functioning, folding, quality control (QC), and degradation systems. Following assembly on membrane-bound ribosomes, the unfolded polypeptides enter into the ER lumen for a chaperone-assisted folding to their correct three-dimensional conformation (Hetz et al., 2020) to enable them to perform their assigned biological functions. Other post-translational modifications in the ER include $\mathrm{N}$-linked glycosylation and disulfide bond formation. Proteins that get folded successfully leave the ER and move towards their final destination through the secretory pathway.

The protein folding is an intrinsically error-prone process with nearly $30 \%$ of the newly synthesized protein folded inappropriately (Balchin et al., 2016). When the folding fails, misfolded polypeptides are retained in the ER by QC mechanisms (Figure 1). The terminally misfolded and aggregated proteins are retrotranslocated into the cytosol to be degraded by endoplasmicreticulum-associated degradation (ERAD) machinery (Li et al., 2017a). ERAD is an essential component of the ER QC system that clears toxic misfolded proteins via an ER-specific ubiquitin/proteasome system involving ubiquitin-activating enzyme (E1), ubiquitin-conjugating enzyme (E2), ubiquitin ligase (E3), and 26S proteasome system. Selective autophagy of ER termed ER phagy, which includes vacuolar degradation of cytoplasmic components, is another component of the ER QC process. Activation of autophagy leads to the de novo formation of double-membrane vesicles termed as autophagosomes at the ER that envelop damaged or superfluous cell components and traffic them to vacuoles for degradation to simple molecules for recycling them back into the cytosol (Wirawan et al., 2012; Marshall and Vierstra, 2018; Bao and Bassham, 2020).

Endoplasmic reticulum protein folding, export and degradation machinery can manage the protein folding demands under the homeostatic state. However, under certain physiological conditions or environmental stresses, the ER gets overwhelmed with misfolded proteins leading to ER stress (Figure 1). To cope with the ER stress, the ER triggers an adaptive program, the unfolded protein response (UPR) (Buchberger et al., 2010; Liu and Howell, 2010; Angelos et al., 2017). In contrast, a cytosolic protein response (CPR) involving specific heat shock factors functions to maintain protein homeostasis in the cytosol (Sugio et al., 2009). The CPR involves heat shock caused activation HSFs leading to enhanced expression of genes encoding heat shock proteins (HSPs). HSPs function as molecular chaperones to counteract protein aggregation and target misfolded proteins for degradation (Buchberger et al., 2010; Hartl et al., 2011; Li et al., 2017a). The compartmentalization of CPR and the ER UPR, with their own distinct chaperones, permits independent responses to disorders in protein folding processes.

The UPR response signature is enhanced expression of genes encoding ER chaperones and the components of the ERAD system (Martínez and Chrispeels, 2003). The UPR activation to prevent the accumulation of unfolded or misfolded proteins in the ER includes ER-localized sensor protein inositol requiring enzyme 1 (IRE1) (Deng et al., 2011). IRE1 functions as an RNA splicing factor whose principal substrate in plants is mRNA encoding the transcription factor bZIP60. Upon its activation by ER stress, IRE1 splices bZIP60 mRNA and produces a form that encodes a bZIP60 protein lacking transmembrane domain (Li and Howell, 2021). Another arm of the UPR pathway involves stress-induced membrane-associated transcription factors, bZIP17 and bZIP28. Molecular chaperones in the ER, including immunoglobulin-binding protein (BiP), a heat shock protein (Hsp 70) family chaperone, Calnexin (CNX), and Calreticulin (CRT), play important roles in ER QC. CNX and CRT mediate folding of Asn-linked glycoproteins trafficking through the ER (Leach and Williams, 2003). Heat shock 70$\mathrm{kDa}$ proteins transiently bind to their client proteins through an ATP hydrolysis and ATP rebinding cycle (Mayer and Gierasch, 2019). This cycle is regulated by DnaJ/Hsp40 (heat shock protein 40 ) proteins, which contain J-domain a $\sim 70$ amino acid signature sequence region through which they bind to Hsp70s (Kampinga and Craig, 2010).

\section{ENDOPLASMIC RETICULUM STRESS AND MALE REPRODUCTIVE DEVELOPMENT}

Plants, being sessile, cannot move to avoid adverse effects of heat waves that are increasing in duration and frequency due to current global climate change conditions. Though heat stress adversely impacts all plant growth stages, the plant reproductive development remains the most vulnerable stage of the life cycle. This vulnerability at the reproductive stage leads to a significant reduction in seed set and crop yields. The pollen development and pollination are particularly vulnerable to heat stress events as elevated temperatures during pollen development can trigger pollen abortion (Reiu et al., 2017; Begcy et al., 2019; Lohani et al., 2020, 2021). Recent investigations have uncovered the crucial role of the UPR for ensuring normal pollen development and successful fertilization (Deng et al., 2013, 2016; Fragkostefanakis et al., 2016). An active UPR pathway is required to meet the high demands of secretory proteins during normal development even in the absence of exogenous stresses (Deng et al., 2013). The knockout mutations in the UPR signaling pathway genes result in pollen developmental abnormalities primarily resulting in male sterility (Table 1). In this review, we focus on the ER stress pathways concerning pollen vulnerability to heat stress conditions.

\section{ENDOPLASMIC RETICULUM STRESS PATHWAYS AND POLLEN DEVELOPMENT}

The process of pollen development from meiocytes to microspores involves intense protein biosynthesis and trafficking of secretory proteins through ER and Golgi apparatus. Arabidopsis mutants for genes involved in the ER to Golgi trafficking exhibit male sterility phenotype (Conger et al., 2011; Tanaka et al., 2013; Deng et al., 2016). High requirement for secretory proteins in developing pollen triggers ER stress constitutively. This constitutive functioning of UPR has been 


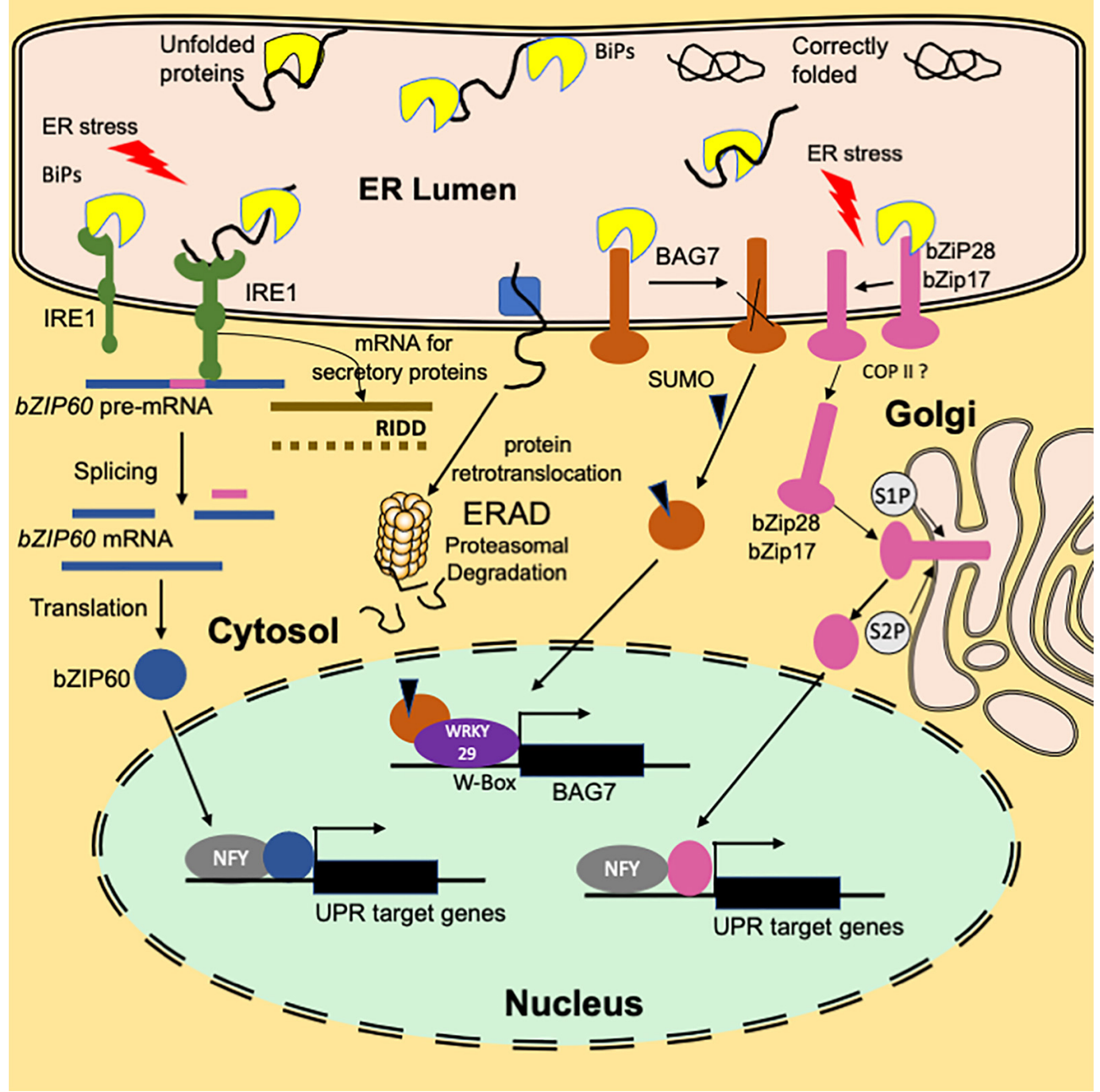

FIGURE 1 | An overview of the functioning of plant ER stress signaling in response to heat stress. A branch of the UPR signaling pathway involves ER transmembrane sensor, IRE1, that propagates the UPR signal from ER to the cytosol. Association with luminal BIP keeps IRE1 in an inactive monomer form. Under ER stress conditions, BIP dissociates from the sensor end of IRE1 to facilitate the folding of the accumulated unfolded proteins. The binding of unfolded proteins to the luminal domain of IRE1 triggers dimerization (or oligomerization) and activation of RNase activity that cleaves bZIP60(u) mRNA resulting in a spliced variant bZIP60(s). Translation of the spliced variant leads to the synthesis of active bZIP60 TF protein whose transport to nucleus activates the stress-responsive genes. Another function of IRE1 is IRE1-Dependent RNA Decay (RIDD) that involves degradation of ribosome-associated RNAs encoding secretory proteins. Dissociation of BIP from ER-anchored transcription factors bZIP28/17 results in their mobilization to Golgi. In the Golgi, these TFs are processed to bZIP17(p) and bZIP28 (p) by S1P and S2P proteases to release cytosolic facing domains that are further transported to the nucleus. In the nucleus, bZIP28/17 bind to ER stress response elements to upregulate the transcription of UPR genes. Another branch of UPR involves an ER-resident transcription factor, BAG7. BAG7 is involved in UPR in response to heat and cold stress conditions by acting as a co-chaperone to prevent the accumulation of unfolded proteins. Under heat stress conditions, BAG7 is sumoylated, released from ER by protease and then translocated to the nucleus where it interacts with WRKY29 to regulate BAG7 and other chaperone expression.

reported to be essential for pollen development (Deng et al., 2016). This conclusion is also supported by the presence of spliced forms of bZIP60 in Arabidopsis male reproductive tissues under normal conditions (Iwata et al., 2008; Deng et al., 2016). The transcriptome-wide mining of male meiocytes and microspores from Arabidopsis plants growing under normal conditions reveals highly elevated expression of most of the ER stress and UPR component genes (Figure 2). Many of these genes show the highest expression levels in diploid meiocytes (microspore mother cells) undergoing meiosis. ER stress component genes highly expressed in the meiocytes belong to UPR, ERAD, and the ER autophagy programs. Among most conspicuous ER phagy genes are those encoding members of Respiratory Burst Oxidases Homolog ( $\mathrm{RBOH}$ ) family, which comprises $10 \mathrm{NADPH}$ oxidase genes in Arabidopsis (Chang et al., 2016). Seven out of 10 gene members show highly elevated expression in meiocytes. The majority of the knockout mutants of Arabidopsis ER stress-related genes involved in UPR, ERAD, 
TABLE 1 | A summary of Arabidopsis ER stress response genes and roles as determined by fertility phenotypes in gene knockout mutants.

\begin{tabular}{|c|c|c|c|c|c|c|}
\hline Gene name & $\begin{array}{l}\text { Arabidopsis } \\
\text { Gene id }\end{array}$ & $\begin{array}{l}\text { Gene Product } \\
\text { Localization }\end{array}$ & $\begin{array}{l}\text { Arabidopsis } \\
\text { Mutant }\end{array}$ & $\begin{array}{l}\text { Pollen Development Phenotype at } \\
\text { Normal Temperature }\end{array}$ & $\begin{array}{l}\text { Pollen Development Phenotype } \\
\text { under Heat Stress }\end{array}$ & References \\
\hline $\begin{array}{l}\text { bZIP28; BASIC } \\
\text { REGION/LEUCINE ZIPPER } \\
\text { MOTIF } 28\end{array}$ & AT3G10800 & $\begin{array}{l}\text { ER membrane, } \\
\text { Cytoplasm, Nucleus }\end{array}$ & $\begin{array}{l}\text { bzip28 bzip60 } \\
\text { double mutant }\end{array}$ & Normal fertility & $\begin{array}{l}\text { Reduced fertility, silique lengths in } \\
\text { bzip28 bzip } 60 \text { double mutant plants } \\
\text { were largely reduced compared with } \\
\text { the wild-type plants }\end{array}$ & Zhang et al., 2017 \\
\hline $\begin{array}{l}\text { bZIP60; BASIC } \\
\text { REGION/LEUCINE ZIPPER } \\
\text { MOTIF } 60\end{array}$ & AT1G42990 & $\begin{array}{l}\text { ER membrane and } \\
\text { nucleus }\end{array}$ & & & & \\
\hline $\begin{array}{l}\text { IRE1a; INOSITOL } \\
\text { REQUIRING 1A }\end{array}$ & AT2G17520 & ER membrane & $\begin{array}{l}\text { ire1a ire } 1 b \\
\text { double mutant }\end{array}$ & Normal viable pollen & $\begin{array}{l}\text { Temperature-sensitive male sterility, } \\
\text { improper deposition of pollen coat } \\
\text { materials possibly due to tapetal } \\
\text { defects, shortened siliques generally } \\
\text { devoid of seeds }\end{array}$ & Deng et al., 2016 \\
\hline $\begin{array}{l}\text { IRE1b; INOSITOL } \\
\text { REQUIRING 1B }\end{array}$ & AT5G24360 & & & & & \\
\hline $\begin{array}{l}\text { CNX1; CALNEXIN } \\
\text { HOMOLOG } 1\end{array}$ & AT5G61790 & ER membrane & cnx 1 crt 1 crt 2 crt3 & $\begin{array}{l}\text { Diverse effect on pollen viability and } \\
\text { pollen tube growth, leading to a } \\
\text { significant reduction pollen mediated } \\
\text { transmission }\end{array}$ & & Vu et al., 2017 \\
\hline CRT1; CALRETICULIN1 & AT1G56340 & $\begin{array}{l}\text { ER and vacuole } \\
\text { membrane, } \\
\text { secretory vesicles }\end{array}$ & & & & \\
\hline CRT2; CALRETICULIN2 & AT1G09210 & $\begin{array}{l}\text { ER and vacuole } \\
\text { membrane, } \\
\text { secretory vesicles }\end{array}$ & $\begin{array}{l}\text { cnx } 1 \text { cnx } 2 \text { crt } 1 \text { crt } 2 \\
\text { crt3 }\end{array}$ & $\begin{array}{l}\text { Lethal-no pollen mediated } \\
\text { transmission }\end{array}$ & & \\
\hline CRT3; CALRETICULIN3 & AT1G08450 & ER lumen & & & & \\
\hline $\begin{array}{l}\text { BiP1; ER localized member } \\
\text { of HSP70 family }\end{array}$ & AT5G28540 & ER lumen and nucleus & $\begin{array}{l}\text { bip1 bip2 } \\
\text { double mutant }\end{array}$ & $\begin{array}{l}\text { Significant reduction in pollen tube } \\
\text { growth activity }\end{array}$ & & Maruyama et al., 2010 \\
\hline $\begin{array}{l}\text { BiP2; LUMINAL BINDING } \\
\text { PROTEIN }\end{array}$ & AT5G42020 & ER lumen and nucleus & $\begin{array}{l}\text { bip1 bip2 bip3 } \\
\text { triple mutant }\end{array}$ & $\begin{array}{l}\text { Lethality of pollen due to defects in } \\
\text { mitosis } 1 \text {, bicellular stage that contained } \\
\text { one or two abnormal microspores with } \\
\text { one nucleus }\end{array}$ & & Maruyama et al., 2014 \\
\hline $\begin{array}{l}\text { BiP3; HSP7O FAMILY } \\
\text { PROTEIN }\end{array}$ & AT1G09080 & ER lumen and nucleus & & & & \\
\hline $\begin{array}{l}\text { SHD/HSP90; SHEPHERD, } \\
\text { HEAT SHOCK PROTEIN } \\
\text { 90-7 }\end{array}$ & AT4G24190 & ER lumen & shd & $\begin{array}{l}\text { Defects in pollen-tube elongation or } \\
\text { penetration into the style }\end{array}$ & Increased the severity of the defects & Ishiguro et al., 2002 \\
\hline $\begin{array}{l}\text { ERdj2A/SEC. } \\
63-1 ; J-D o m a i n \text { protein }\end{array}$ & AT1G79940 & ER membrane & $\begin{array}{l}\text { aterdj2a-1, } \\
\text { aterdj2a-2 }\end{array}$ & $\begin{array}{l}\text { Defects in pollen germination but not } \\
\text { pollen development }\end{array}$ & & Yamamoto et al., 2008 \\
\hline
\end{tabular}


TABLE 1 | Continued

\begin{tabular}{|c|c|c|c|c|c|c|}
\hline Gene name & $\begin{array}{l}\text { Arabidopsis } \\
\text { Gene id }\end{array}$ & $\begin{array}{l}\text { Gene Product } \\
\text { Localization }\end{array}$ & $\begin{array}{l}\text { Arabidopsis } \\
\text { Mutant }\end{array}$ & $\begin{array}{l}\text { Pollen Development Phenotype at } \\
\text { Normal Temperature }\end{array}$ & $\begin{array}{l}\text { Pollen Development Phenotype } \\
\text { under Heat Stress }\end{array}$ & References \\
\hline $\begin{array}{l}\text { ERdj3ATMS } 1 ; \\
\text { THERMOSENSITIVE MALE } \\
\text { STERILE } 1\end{array}$ & АT3G08970 & ER lumen & tms 1-1 & $\begin{array}{l}\text { The fertility of tms } 1-1 \text { plants was slightly } \\
\text { affected, with some ovules in the lower } \\
\text { part of the siliques unfertilized }\end{array}$ & $\begin{array}{l}\text { Greatly retarded pollen tube growth in } \\
\text { the transmitting tract, resulting in a } \\
\text { significant reduction in male fertility }\end{array}$ & Yang et al., 2009 \\
\hline \multirow[t]{2}{*}{ ERdj3B; J-Domain protein } & АT3G62600 & ER lumen & 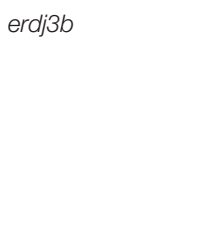 & Normal flower development and fertility & $\begin{array}{l}\text { Produced few seeds at high } \\
\text { temperatures due to anther } \\
\text { development defects, abnormal } \\
\text { enlargement of tapetum cells with } \\
\text { vacuolated and aborted microspores, } \\
\text { defective pollen release from the } \\
\text { anthers }\end{array}$ & Yamamoto et al., 2020 \\
\hline & & & atp58ipk aterdj3b & Defects in male gametophyte & & Yamamoto et al., 2008 \\
\hline \multirow[t]{2}{*}{$\begin{array}{l}\text { Sec62; protein with } \\
\text { similarity to yeast Sec62p. }\end{array}$} & АТЗG20920 & ER membrane & $\begin{array}{l}\text { atsec62 (T-DNA } \\
\text { and amiRNAi) }\end{array}$ & $\begin{array}{l}\text { Smaller and round depressed pollens, } \\
\text { defects in pollen development, smaller, } \\
\text { aborted, and lesser number of siliques }\end{array}$ & & Hu et al., 2020; \\
\hline & & & atsec62 & $\begin{array}{l}\text { Aborted and mostly empty siliques, } \\
\text { delayed anther and pollen } \\
\text { development, less pollen released from } \\
\text { mutant anthers and reduced pollen } \\
\text { germination }\end{array}$ & Pollen hardly germinated & Mitterreiter et al., 2020 \\
\hline $\begin{array}{l}\text { PDI9; PROTEIN DISULFIDE } \\
\text { ISOMERASE } 9\end{array}$ & AT2G32920 & ER lumen & pdi9 & Normal viable pollen & $\begin{array}{l}\text { Disruptions in the reticulated pattern of } \\
\text { the exine and an increased adhesion of } \\
\text { pollen grains }\end{array}$ & Feldeverd et al., 2020 \\
\hline $\begin{array}{l}\text { PDI10; PROTEIN } \\
\text { DISULFIDE ISOMERASE } 10\end{array}$ & AT1G04980 & ER lumen & $\begin{array}{l}\text { pdi9 pdi10 } \\
\text { double mutant }\end{array}$ & Normal viable pollen & Completely lost exine reticulation & \\
\hline $\begin{array}{l}\text { POD1; POLLEN } \\
\text { DEFECTIVE in } \\
\text { GUIDANCE } 1\end{array}$ & AT1G67960 & ER lumen & pod1 & $\begin{array}{l}\text { Pollen tubes fail to target the female } \\
\text { gametophyte, defective in micropylar } \\
\text { pollen tube guidance leading to zygotic } \\
\text { lethality }\end{array}$ & & Li et al., 2011 \\
\hline $\begin{array}{l}\text { UTR1, UDP-GALACTOSE } \\
\text { TRANSPORTER } 1\end{array}$ & AT2G02810 & $\begin{array}{l}\text { ER and golgi } \\
\text { membranes }\end{array}$ & $\begin{array}{l}\text { utr1 utr3 double } \\
\text { mutant }\end{array}$ & $\begin{array}{l}\text { Abnormalities in both male and female } \\
\text { germ line development, haploid atutr } 1 \\
\text { atutr3 combination is a fully penetrant } \\
\text { lethal mutation for the male } \\
\text { gametophyte and is partially penetrant } \\
\text { for the female gametophyte }\end{array}$ & & Reyes et al., 2010 \\
\hline
\end{tabular}

UTR3, UDP-GALACTOSE $\quad$ AT1G14360

TRANSPORTER 3

STT3a; STAUROSPORN

AT5G19690

ER membrane

stt3a-1 stt3b-1

Gametophytic lethal

Koiwa et al., 2003

SENSITIVE 3-LIKE A 
TABLE 1 | Continued

\begin{tabular}{|c|c|c|c|c|c|c|}
\hline Gene name & $\begin{array}{l}\text { Arabidopsis } \\
\text { Gene id }\end{array}$ & $\begin{array}{l}\text { Gene Product } \\
\text { Localization }\end{array}$ & $\begin{array}{l}\text { Arabidopsis } \\
\text { Mutant }\end{array}$ & $\begin{array}{l}\text { Pollen Development Phenotype at } \\
\text { Normal Temperature }\end{array}$ & $\begin{array}{l}\text { Pollen Development Phenotype } \\
\text { under Heat Stress }\end{array}$ & References \\
\hline $\begin{array}{l}\text { SERK1; SOMATIC } \\
\text { EMBRYROGENESIS } \\
\text { RECEPTOR-LIKE } \\
\text { KINASE } 1\end{array}$ & AT1G71830 & ER and cell membrane & serk1 serk2 & $\begin{array}{l}\text { Completely male sterile due to a failure } \\
\text { in tapetum specification, double mutant } \\
\text { anthers lack development of the tapetal } \\
\text { cell layer leading to the microspore } \\
\text { abortion and male sterility }\end{array}$ & & $\begin{array}{l}\text { Albrecht et al., 2005; } \\
\text { Colcombet et al., } 2005\end{array}$ \\
\hline $\begin{array}{l}\text { SAR1; SECRETION } \\
\text { ASSOCIATED RAS } 1\end{array}$ & AT1G56330 & $\begin{array}{l}\text { ER-, COPII vesicle coat } \\
\text { and golgi apparatus }\end{array}$ & $\begin{array}{l}\text { sar1b } \\
\text { sar1bsar1c } \\
\text { double mutant }\end{array}$ & $\begin{array}{l}\text { Malfunctioning tapetum, leading to } \\
\text { male sterility. Microspores in sar1b } \\
\text { pollen sacs started to degenerate. The } \\
\text { plasma membrane (PM) of microspores } \\
\text { in sar1b pollen sacs was detached from } \\
\text { the cell wall, and at anther dehiscence, } \\
\text { sar1b pollen sacs contained only a pile } \\
\text { of cellular debris } \\
\text { Microspores aborted at anther } \\
\text { developmental stage 10, arrest of } \\
\text { pollen development at Pollen Mitosis I }\end{array}$ & & Liang et al., 2020 \\
\hline $\begin{array}{l}\text { PDR2, PHOSPHATE } \\
\text { DEFICIENCY RESPONSE } 2\end{array}$ & AT5G23630 & ER membrane & mia mutants & $\begin{array}{l}\text { Male gametogenesis impaired anthers } \\
\text { (mia) show severe reduction in fertility. } \\
\text { Mutant microspores fail to separate } \\
\text { from tetrads and fragile pollen grains } \\
\text { with an abnormal morphology and } \\
\text { altered cell wall structure. }\end{array}$ & & Jakobsen et al., 2005 \\
\hline $\begin{array}{l}\text { AEP1; ASPARAGINYL } \\
\text { ENDOPEPTIDASE } 1\end{array}$ & AT2G25940 & $\begin{array}{l}\text { Protein storage } \\
\text { vacuole, Vacuole }\end{array}$ & Bvpe & $\begin{array}{l}\text { Abnormal degradation of the tapetum, } \\
\text { incomplete pollen cytoplasm } \\
\text { development, with few oil bodies and } \\
\text { an indistinct generative cell. Some of } \\
\text { the pollen grains were shrunken and } \\
\text { abnormally shaped, immature pollen } \\
\text { still contained numerous small vacuoles }\end{array}$ & & Cheng et al., 2020 \\
\hline $\begin{array}{l}\text { CEP1; CYSTEINE } \\
\text { ENDOPEPTIDASE } 1\end{array}$ & AT5G50260 & ER and vacuole & cep1 & $\begin{array}{l}\text { Aborted tapetal PCD, reduced male } \\
\text { fertility due to impaired pollen } \\
\text { development and abnormal pollen exine }\end{array}$ & & Zhang et al., 2014 \\
\hline $\begin{array}{l}\text { RBOHE; Riboflavin } \\
\text { Synthase-Like Family } \\
\text { Protein }\end{array}$ & AT1G19230 & $\begin{array}{l}\text { Multi pass membrane } \\
\text { protein }\end{array}$ & rbohe-2 & $\begin{array}{l}\text { Delayed degeneration of tapetum, } \\
\text { reduced pollen viability, abnormal pollen } \\
\text { grain shape and exine layer }\end{array}$ & & Xie et al., 2014 \\
\hline $\begin{array}{l}\text { RBOHJ; RESPIRATORY } \\
\text { BURST OXIDASE } \\
\text { HOMOLOG J }\end{array}$ & AT3G45810 & $\begin{array}{l}\text { Multi pass membrane } \\
\text { protein }\end{array}$ & $\begin{array}{l}\text { rbohH rbohJ } \\
\text { double mutant }\end{array}$ & $\begin{array}{l}\text { Pollen tip growth severely impaired due } \\
\text { to impaired ROS accumulation }\end{array}$ & & Kaya et al., 2014 \\
\hline $\begin{array}{l}\text { RBOHH; RESPIRATORY } \\
\text { BURST OXIDASE } \\
\text { HOMOLOG J }\end{array}$ & AT5G60010 & $\begin{array}{l}\text { Multi pass membrane } \\
\text { protein }\end{array}$ & & & & \\
\hline
\end{tabular}


and ER-autophagy processes show loss of fertility phenotypes in plants grown under non-stressed conditions (Table 1). These observations highlight the essential role of ER homeostasis in permitting normal pollen development.

ROS generated by these NADPH-dependent oxidases (Nox) complex control various developmental processes including programmed tapetal cell death and is an essential component of developing pollen-tapetum interaction network (Xie et al., 2014). Other ER autophagy-related genes showing a high level of expression in diploid meiocytes include Metacaspase 5 (MC5) and Bcl-2-associated athanogene 7 (BAG7). MC5 and BAG7 are involved in the programmed cell death (PCD) network. Metacaspases are cysteine proteases involved in PCD that are distantly related to animal caspases (Kørner et al., 2015). MC5 has been shown as a positive regulator of ER stress-induced PCD (Sobri and Zulfazli, 2016). AtBAG7 is a member of the Arabidopsis BAG family encoding plant homologs of mammalian regulators of apoptosis (Li et al., 2017b). These ER-localized proteins play a crucial role in maintaining UPR in response to external stresses (Li et al., 2017b; Nawkar et al., 2018).

\section{ENDOPLASMIC RETICULUM STRESS DURING POST-MEIOTIC DEVELOPMENT AND POLLEN TUBE GROWTH}

In post-meiotic stages of pollen developmental progression, several ER stress component genes show expression at the unicellular microspore and bicellular stage. These include genes encoding BiPs, both IRE1 isoforms (IRE1a and IRE1b), CRT, CNX, site-specific proteases (S1P and S2P), and NAC family of membrane-bound transcription factors.

Another noticeable feature of the developing pollen transcriptome is high-level expression of ERAD genes. Gene encoding UBC32, a ubiquitin-conjugating enzyme (E2) localized in the ER membrane, is expressed constitutively in the male meiocytes. Its expression, although much lower in microspores, shows an increase during the pollen development. The Arabidopsis genome contains five J-domain encoding genes (AtERdj3A, AtERdj3B, AtP58 ${ }^{I P K}$, AtERdj2A, and AtERdj2B) that encode Hsp40 family co-chaperones of Hsp70. The Arabidopsis Thermosensitive Male Sterile 1 (TMS1) encoding a J-domain protein identical to AtERdj3A plays a significant role in determining thermotolerance of pollen and vegetative tissues (Ma et al., 2015). Arabidopsis plants carrying a knockout mutation in TMS1 grown at $30^{\circ} \mathrm{C}$ were reported to show a significant decrease in male fertility resulting from retarded pollen tube growth in the stylar transmitting tract (Yang et al., 2009). Recently, Yamamoto et al. (2020) reported that a second ER-resident Arabidopsis J-domain protein, AtERdj3B, also plays a critical role in another development at elevated temperatures. The erdj3b mutant showed a significantly reduced seed set at an elevated temperature of $29^{\circ} \mathrm{C}$. This reduced seed set phenotype could be rescued in mutants by introducing ERDJ3B gene expressing under its promoter. Interestingly, this defect could be rescued by overexpression of ERDJ3A gene regulated by the $E R D J 3 B$ promoter. The erdj3b mutant plants grown at $29^{\circ} \mathrm{C}$ revealed collapsed pollen with abnormalities in their pollen coats. Furthermore, the authors addressed whether pollen-coat abnormality in erdj3 at elevated temperatures is caused by the effect of the mutation in tapetal cells. The transformation of erdj3b mutant plants with ERDJ3B gene expressing under a tapetum-specific promoter led to partial suppression of the reduced seed set phenotype in mutant plants growing at $29^{\circ} \mathrm{C}$. Interestingly, this study could not observe fertility defects in erdj3a-1 or erdj3a-2 mutants grown at $29^{\circ} \mathrm{C}$. It was further proposed that among ER-localized three J proteins, heat stress-sensitive fertility defect results only from defective interaction of only EEdj3B with BiP. Three Hsp70 chaperone proteins ( $\mathrm{BiP} 1, \mathrm{BiP} 2$, and $\mathrm{BiP} 3)$ are localized in $\mathrm{ER}$ of Arabidopsis thaliana (Yamamoto et al., 2008; Ma et al., 2015). $\mathrm{BiP} 1$ and BiP2 are 99\% identical and have been reported to be expressed ubiquitously. Interestingly, BiP1 and BiP2 expression is significantly upregulated in Arabidopsis meiocytes (Figure 2). BiP3 that shows less identity with the other two paralogs is expressed only under ER stress conditions (Maruyama et al., 2015). Maruyama et al. (2010) have shown that the Arabidopsis bip1/bip2 double mutant shows normal pollen viability but retarded pollen tube growth both in vitro and in vivo. Since the secretion of cell wall proteins is crucial for pollen tube growth, the reduced $\mathrm{BiP}$ level led to retarded pollen tubes growth rates due to decline in protein translocation, protein folding, and ER QC activities.

Recently, Poidevin et al. (2020) used a Riboprofiling technique to unravel the effect of heat stress on transcriptome and translatome of mature and in vitro germinated Arabidopsis pollen grains. Riboprofiling (Ribo-seq) allows accurate comparison of cellular transcriptome with translatome (Ingolia et al., 2009; Hsu et al., 2016). Riboprofiling data showed transcriptional and translational level upregulation of DNA-J chaperones and ER stress related in germinated pollen, induced by the heat stress. These upregulated genes include Hsp70 BiPs (BiP1, BiP2, and BiP3), the DNAJ chaperones (ERDJ3A, ERDJ3B, and P581PK), Calnexin and Calreticulin (CNX1, CRT1a, and CRT1b), and proteins involved in ERAD pathway such as DER1 and DER2.1. The key transcription factors, bZIP28, bZIP60, and NF-YC2, are transcribed and translated in pollen tubes (Poidevin et al., 2020). The authors conclude from their data that the Arabidopsis pollen can respond to heat stress by enhancing the expression of thermotolerance genes. However, their data are based on transcriptome and translatome profiling of in vitro germinated pollen grains. The transcriptional repertoire of pollen tubes penetrating the stigma and styler tissues is very different from that of in vitro germinated pollen tubes with in vivo growing tubes expressing a substantially larger fraction of the genome (Qin et al., 2009). The analysis of transcriptome data of Arabidopsis pollen tubes growing in vivo shows default upregulation of expression of ER stress genes in the absence of external stress (Figure 2).

The transcriptional activity of ER stress-related genes in the pollen germinating in vitro is comparable to mature ungerminated pollen with no significant change in expression levels. However, the pollen tubes growing in the styler transmitting tissues show significant upregulation of several 
A

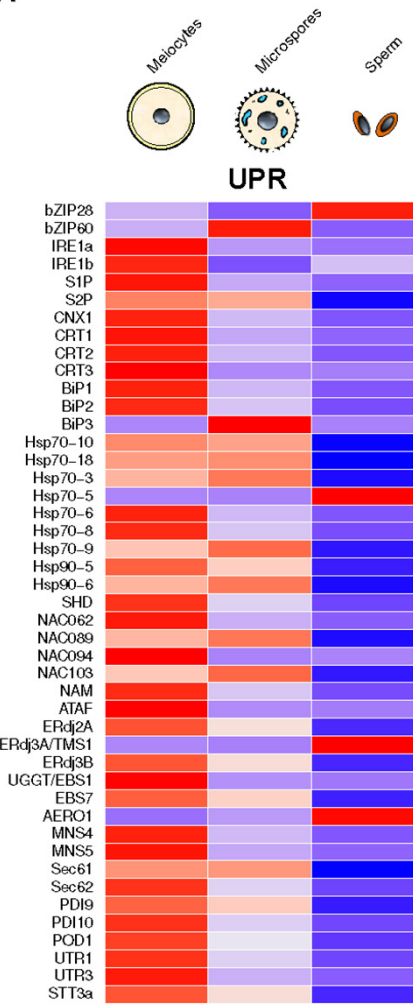

ERAD

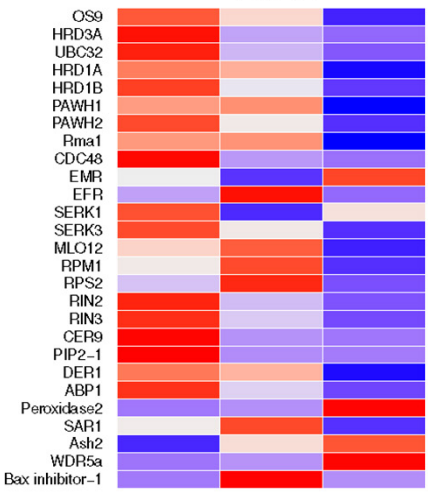

ER-Autophagy

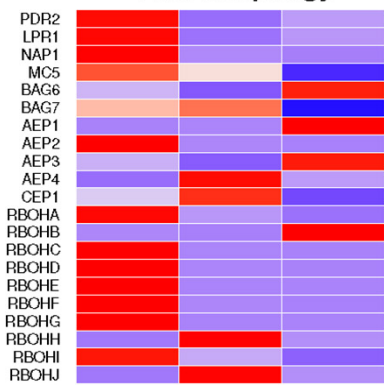

B
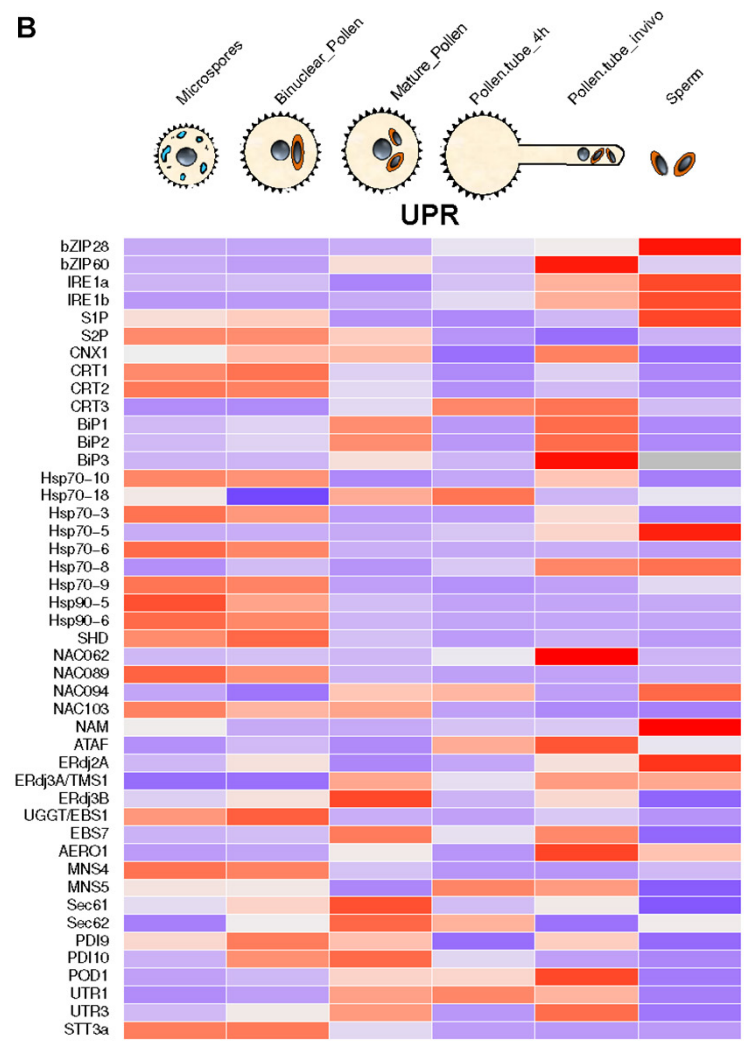

ERAD

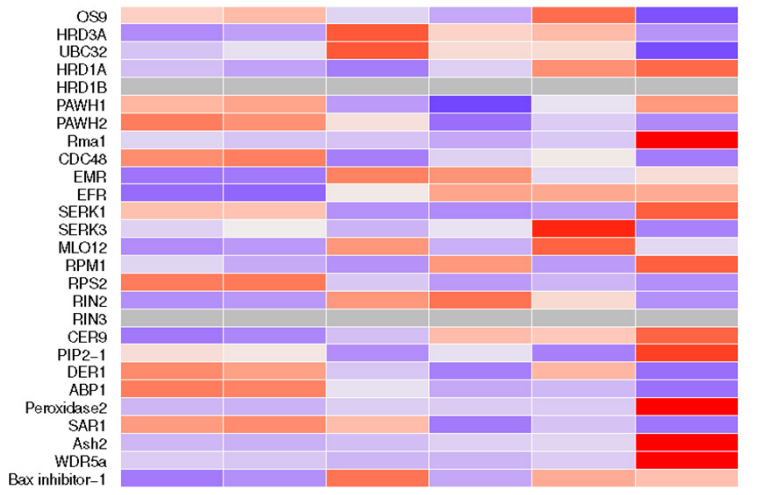

ER-Autophagy

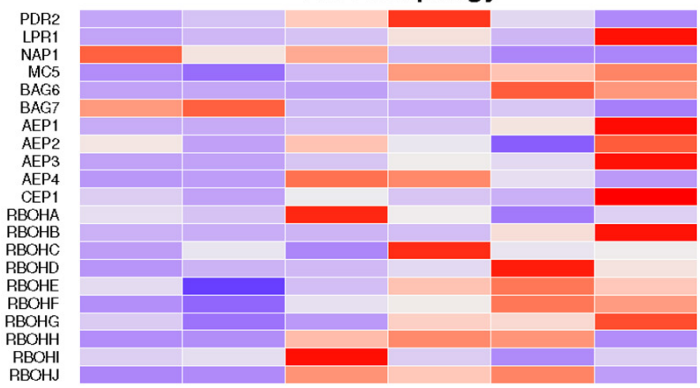

Z-score A

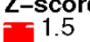

$-1$

0.5

0.5

$-1$

Z-score_B

$-2$

$-1$

0

$-1$

FIGURE 2 | Annotation and expression of ER stress component genes in Arabidopsis developing pollen, pollen tubes, and sperm cells. The data were compiled using the gene expression obtained from RNA-seq based analysis (A) or microarrays (B). RNA-seq data sets from previously published literature were downloaded from the NCBI Sequence Read Archive database. For Microarray data, the expression values were downloaded from the Arabidopsis Heat Tree Viewer (http://arabidopsis-heat-tree.org/). The gray color in the heatmap denotes missing values. Full details available in Supplementary File $\mathbf{1 .}$ 
ER stress component genes such as bZIP60, both isoforms of IRE1, S2P, NAC062, J-domain protein ERdj2a, and AERO1 (ER oxidoreductin 1). The observed stark differences in the gene expression patterns in pollen tubes growing in vitro or in vivo are predictable as pollen tubes attain about $135 \mu \mathrm{m}$ length in vitro (Dickinson et al., 2018), while pollen tubes growing in vivo have to traverse stigma/style length. Rapidly growing pollen tubes show high trafficking with secretory vesicles providing membrane components (Campanoni and Blatt, 2007). High demands for secretory proteins likely trigger UPR in the pollen tubes. Interestingly, Arabidopsis mutants for many UPR genes display pollen germination and pollen tube growth defects (Ishiguro et al., 2002; Yamamoto et al., 2008; Maruyama et al., 2010; Deng et al., 2013).

The ERAD component genes expressing highly in pollen tubes include genes encoding OS9, HRD3A, PAWH1, Rma1, MLO12, CER9, EBS7, and Bax-inhibitor-1. High ER-associated protein degradation appears to be a hallmark of rapidly elongating pollen tubes. ERAD involves modifying target unfolded/misfolded proteins with ubiquitin, removal from the ER, followed by degradation by the cytoplasmic 26S proteasome (Preston and Brodsky, 2017). AtOS9 is an Arabidopsis homolog of mammalian ER luminal lectin OS9 with binding specificity for asparaginelinked glycan on misfolded proteins. An interesting feature of the pollen tube transcriptome is a high expression of ER phagy-related genes encoding BAG6, MC5, AEP1, RBOHH, and $\mathrm{RBOHJ}$ (Respiratory Burst Homologs). RBOHH and $\mathrm{RBOHJ}$ encode NADPH oxidases containing $\mathrm{Ca}^{2+}$ binding EFhand motifs and possessing $\mathrm{Ca}^{2+}$-induced ROS production activity. While Arabidopsis single mutants, rbohH and rbohJ, attain pollen tube growth comparable to wild type, the double mutant showed severe impairment of pollen tube growth (Kaya et al., 2014). Also, in vitro grown pollen tubes of the rbohH and rbohJ double mutants rupture easily (Boisson-Dernier et al., 2013).

\section{EXPRESSION OF ER STRESS-RELATED GENES IN SPERM CELLS}

Pollen is largely made up of vegetative cell that forms a pollen tube, which acts as a conduit to transmit male germline, the non-motile sperm cells, into the female gametophyte to execute double fertilization, a defining feature of flowering plants (Singh and Bhalla, 2007). The male germline is initiated by asymmetric division of the microspore leading to the formation of much smaller generative cell enveloped within the larger vegetative cell. The generative cell divides once again to produce two sperm cells required for double fertilization (Russell and Jones, 2015). In the mature pollen, sperm cells may comprise much less than $1 \%$ of the pollen volume (Russell and Strout, 2005; Russell and Jones, 2015). For a long time, the inconspicuous generative and sperm cells were considered passive carriers of male genetic lineage. However, it was later shown that both these cells are largely transcriptionally and translationally distinct from much larger vegetative cells (Xu et al., 1999; Singh and Bhalla, 2007). Transcriptomic analysis using either microarrays or RNA-seq approaches have highlighted the highly divergent nature of gene expression in generative and sperm cells compared to that of the vegetative cells (Okada et al., 2007; Singh et al., 2008; Russell et al., 2012; Russell and Jones, 2015). A survey of ER stress-related gene expression in Arabidopsis sperm isolated from mature pollen reveals constitutive expression of several ER stress-related genes relating to UPR, ERAD, and ER phagy with remarkably high expression of UPR genes encoding bZIP 28, ERdj3A/TMS1, and AERO1. ERAD-related genes showing significant expression in sperm cells include SERK1, Peroxidase 1, Ash2, and WDR5a. ER autophagy-related genes with significant expression in sperm cells include BAG6, AEP1, AEP3, and RBOHB. While the data from microarray and RNA-seq experiments cannot be compared directly, there appears to be a good overall crossplatform concordance particularly among genes showing high expression levels. The quantitative expression pattern of ER stress related in sperm cells is quite distinct from that of total pollen (Figure 2). However, it remains an open question whether the pattern of ER stress gene expression show further changes in sperm cells following heat stress or due to pollen tube growth in female tissues.

\section{FUTURE PERSPECTIVES}

Despite an increasing number of publications on plant reproduction and ER stress response in recent years reporting intriguing findings, there remain open questions about the activation of ER stress and the role this response plays in protecting pollen development and pollination processes from detrimental effects of excessive heat exposure. The cellular trigger for high constitutive activity of ER stress-related genes in diploid meiocytes warrants further investigation. An intriguing possibility is the potential role of cellular hypoxia in triggering UPR in meiocytes. Studies on animal systems have revealed that the activation of UPR is an adaptive response to hypoxic stress (Bartoszewska and Collawn, 2020). Earlier, Kelliher and Walbot (2012) have proposed that meiotic fate in the archesporial cells in the immature anthers is triggered by hypoxia. Future investigations can focus on the potential crosstalk between hypoxia conditions in the anther cavity and triggering of UPR in resident meiocytes.

It has been recognized that pollen development is one of the situations where high demands for secretion triggers ER stress under normal conditions without externally imposed stress (Howell, 2017). Thus, it can be postulated that the protein homeostasis maintained by enhanced protein folding capacity allows normal pollen development to proceed. There is no evidence for the direct interaction between the pollen ER stress response and the transcription factors and downstream pathways linked to regulation of cell fate determination and developmental progression. The constitutive ER stress response leading to nearcapacity functioning of the ER protein folding and trafficking machinery likely diminishes ER's adaptive capacity to adjust to external stresses, resulting in the high sensitivity of pollen to heat stress events. Thus, future studies can be expected to focus on 
investigating the overexpression of key ER signaling components and chaperones as a tool to enhance pollen thermotolerance. This would open new opportunities for engineering crop plants that can offer yield stability in the face of increased frequency of heat waves with crops getting exposed to extreme temperature events.

\section{AUTHOR CONTRIBUTIONS}

NL analyzed the sequencing data. MS conceived the research. MS and PB drafted the manuscript. All authors contributed to the article and approved the submitted version.

\section{REFERENCES}

Albrecht, C., Russinova, E., Hecht, V., Baaijens, E., and De Vries, S. (2005). The Arabidopsis thaliana somatic embryogenesis receptor-like kinases1 and 2 control male sporogenesis. Plant Cell 17, 3337-3349. doi: 10.1105/tpc.105. 036814

Angelos, E., Ruberti, C., Kim, S. J., and Brandizzi, F. (2017). Maintaining the factory: the roles of the unfolded protein response in cellular homeostasis in plants. Plant J. 90, 671-682. doi: 10.1111/tpj.13449

Begcy, K., Nosenko, T., Zhou, L.-Z., Fragner, L., Weckwerth, W., and Dresselhaus, T. (2019). Male sterility in maize after transient heat stress during the tetrad stage of pollen development. Plant Physiol. 181, 683-700. doi: 10.1104/pp.19. 00707

Balchin, D., Hayer-Hartl, M., and Hartl, F. U. (2016). In vivo aspects of protein folding and quality control. Science 353:aac4354. doi: 10.1126/science.aac4354

Bao, Y., and Bassham, D. C. (2020). ER-phagy and its role in ER homeostasis in plants. Plants 9:1771. doi: 10.3390/plants9121771

Bartoszewska, S., and Collawn, J. F. (2020). Unfolded protein response (UPR) integrated signaling networks determine cell fate during hypoxia. Cell. Mol. Biol. Lett. 25, 1-20.

Boisson-Dernier, A., Lituiev, D. S., Nestorova, A., Franck, C. M., Thirugnanarajah, S., and Grossniklaus, U. (2013). ANXUR receptor-like kinases coordinate cell wall integrity with growth at the pollen tube tip via NADPH oxidases. PLoS Biol. 11:e1001719. doi: 10.1371/journal.pbio.1001719

Buchberger, A., Bukau, B., and Sommer, T. (2010). Protein quality control in the cytosol and the endoplasmic reticulum: brothers in arms. Mol. Cell 40, 238-252. doi: 10.1016/j.molcel.2010.10.001

Campanoni, P., and Blatt, M. R. (2007). Membrane trafficking and polar growth in root hairs and pollen tubes. J. Exp. Bot. 58, 65-74. doi: 10.1093/jxb/erl059

Chang, Y. L., Li, W. Y., Miao, H., Yang, S. Q., Li, R., Wang, X., et al. (2016). Comprehensive genomic analysis and expression profiling of the NOX gene families under abiotic stresses and hormones in plants. tubes. Genome Biol. Evol. 8, 791-810. doi: 10.1093/gbe/evw035

Cheng, Z., Guo, X., Zhang, J., Liu, Y., Wang, B., Li, H., et al. (2020). $\beta$ VPE is involved in tapetal degradation and pollen development by activating proprotease maturation in Arabidopsis thaliana. J. Exp. Bot. 71, 1943-1955. doi: $10.1093 /$ jxb/erz560

Colcombet, J., Boisson-Dernier, A., Ros-Palau, R., Vera, C. E., and Schroeder, J. I. (2005). Arabidopsis somatic embryogenesis receptor kinases 1 and 2 are essential for tapetum development and microspore maturation. Plant Cell 17, 3350-3361. doi: 10.1105/tpc.105.036731

Conger, R., Chen, Y., Fornaciari, S., Faso, C., Held, M. A., Renna, L., et al. (2011). Evidence for the involvement of the Arabidopsis SEC24A in male transmission. J. Exp. Bot. 62, 4917-4926. doi: 10.1093/jxb/err174

Deng, Y., Humbert, S., Liu, J.-X., Srivastava, R., Rothstein, S. J., and Howell, S. H. (2011). Heat induces the splicing by IRE1 of a mRNA encoding a transcription factor involved in the unfolded protein response in Arabidopsis. Proc. Natl. Acad. Sci. U.S.A. 108, 7247-7252. doi: 10.1073/pnas.1102117108

Deng, Y., Srivastava, R., and Howell, S. H. (2013). Protein kinase and ribonuclease domains of IRE1 confer stress tolerance, vegetative growth, and reproductive development in Arabidopsis. Proc. Natl. Acad. Sci. U.S.A. 110, 19633-19638. doi: $10.1073 /$ pnas. 1314749110

\section{ACKNOWLEDGMENTS}

The research support from the ARC Discovery Grant DP0988972 and the University of Melbourne postgraduate Research Scholarship is gratefully acknowledged.

\section{SUPPLEMENTARY MATERIAL}

The Supplementary Material for this article can be found online at: https://www.frontiersin.org/articles/10.3389/fpls.2021. 661062/full\#supplementary-material

Deng, Y., Srivastava, R., Quilichini, T. D., Dong, H., Bao, Y., Horner, H. T., et al. (2016). IRE 1, a component of the unfolded protein response signaling pathway, protects pollen development in Arabidopsis from heat stress. Plant J. 88, 193-204. doi: $10.1111 /$ tpj.13239

Dickinson, H., Rodriguez-Enriquez, J., and Grant-Downton, R. (2018). Pollen Germination and Pollen tube growth of Arabidopsis thaliana: in vitro and Semi in vivo Methods. Bio Protoc. 8:e2977.

Feldeverd, E., Porter, B. W., Yuen, C. Y., Iwai, K., Carrillo, R., Smith, T., et al. (2020). The Arabidopsis protein disulfide isomerase subfamily M isoform, PDI9, localizes to the endoplasmic reticulum and influences pollen viability and proper formation of the pollen exine during heat stress. Front. Plant Sci. 11:610052.

Fragkostefanakis, S., Mesihovic, A., Hu, Y., and Schleiff, E. (2016). Unfolded protein response in pollen development and heat stress tolerance. Plant Reprod. 29, 81-91. doi: 10.1007/s00497-016-0276-8

Hartl, F. U., Bracher, A., and Hayer-Hartl, M. (2011). Molecular chaperones in protein folding and proteostasis. Nature 475, 324-332. doi: 10.1038/ nature 10317

Hetz, C., Zhang, K., and Kaufman, R. J. (2020). Mechanisms, regulation and functions of the unfolded protein response. Nat. Rev. Mol. Cell Biol. 21, 421-438. doi: 10.1038/s41580-020-0250-z

Howell, S. H. (2017). When is the unfolded protein response not the unfolded protein response? Plant Sci. 260, 139-143. doi: 10.1016/j.plantsci.2017.03.014

Hsu, P. Y., Calviello, L., Wu, H.-Y. L., Li, F.-W., Rothfels, C. J., Ohler, U., et al. (2016). Super-resolution ribosome profiling reveals unannotated translation events in Arabidopsis. Proc. Natl. Acad. Sci. U.S.A. 113, E7126-E7135.

$\mathrm{Hu}, \mathrm{S}$., Ye, H., Cui, Y., and Jiang, L. (2020). AtSec62 is critical for plant development and is involved in ER-phagy in Arabidopsis thaliana. J. Integrat. Plant Biol. 62, 181-200. doi: 10.1111/jipb.12872

Ingolia, N. T., Ghaemmaghami, S., Newman, J. R., and Weissman, J. S. (2009). Genome-wide analysis in vivo of translation with nucleotide resolution using ribosome profiling. Science 324, 218-223. doi: 10.1126/science.1168978

Ishiguro, S., Watanabe, Y., Ito, N., Nonaka, H., Takeda, N., Sakai, T., et al. (2002). SHEPHERD is the Arabidopsis GRP94 responsible for the formation of functional CLAVATA proteins. EMBO J. 21, 898-908. doi: 10.1093/emboj/21.5. 898

Iwata, Y., Fedoroff, N. V., and Koizumi, N. (2008). Arabidopsis bZIP60 is a proteolysis-activated transcription factor involved in the endoplasmic reticulum stress response. Plant Cell 20, 3107-3121. doi: 10.1105/tpc.108. 061002

Jakobsen, M. K., Poulsen, L. R., Schulz, A., Fleurat-Lessard, P., Møller, A., Husted, S., et al. (2005). Pollen development and fertilization in Arabidopsis is dependent on the male gametogenesis impaired anthers gene encoding a type V P-type ATPase. Genes Dev. 19, 2757-2769. doi: 10.1101/gad.3 57305

Kampinga, H. H., and Craig, E. A. (2010). The HSP70 chaperone machinery: J proteins as drivers of functional specificity. Nat. Rev. Mol. Cell Biol. 11, 579-592. doi: $10.1038 / \mathrm{nrm} 2941$

Kaya, H., Nakajima, R., Iwano, M., Kanaoka, M. M., Kimura, S., Takeda, S., et al. (2014). Ca2+-activated reactive oxygen species production by Arabidopsis $\mathrm{RbohH}$ and RbohJ is essential for proper pollen tube tip growth. Plant Cell 26, 1069-1080. doi: 10.1105/tpc.113.120642 
Kelliher, T., and Walbot, V. (2012). Hypoxia triggers meiotic fate acquisition in maize. Science 337, 345-348. doi: 10.1126/science. 1220080

Koiwa, H., Li, F., Mccully, M. G., Mendoza, I., Koizumi, N., Manabe, Y., et al. (2003). The STT3a subunit isoform of the Arabidopsis oligosaccharyltransferase controls adaptive responses to salt/osmotic stress. Plant Cell 15, 2273-2284. doi: $10.1105 /$ tpc. 013862

Kørner, C. J., Du, X., Vollmer, M. E., and Pajerowska-Mukhtar, K. M. (2015). Endoplasmic reticulum stress signaling in plant immunity-at the crossroad of life and death. Int. J. Mol. Sci. 16, 26582-26598. doi: 10.3390/ijms161125964

Leach, M. R., and Williams, D. B. (2003). "Calnexin and calreticulin, molecular chaperones of the endoplasmic reticulum," in Calreticulin. Molecular Biology Intelligence Unit, eds P. Eggleton and M. Michalak (Boston, MA: Springer), 49-62. doi: 10.1007/978-1-4419-9258-1_6

Li, H.-J., Xue, Y., Jia, D.-J., Wang, T., Hi, D.-Q., Liu, J., et al. (2011). POD1 regulates pollen tube guidance in response to micropylar female signaling and acts in early embryo patterning in Arabidopsis. Plant Cell 23, 3288-3302. doi: 10.1105/tpc.111.088914

Li, L.-M., Lü, S.-Y., and Li, R.-J. (2017a). The Arabidopsis endoplasmic reticulum associated degradation pathways are involved in the regulation of heat stress response. Biochem. Biophys. Res. Commun. 487, 362-367. doi: 10.1016/j.bbrc. 2017.04.066

Li, Y., Williams, B., and Dickman, M. (2017b). Arabidopsis B-cell lymphoma2 (Bcl-2)-associated athanogene 7 (BAG 7)-mediated heat tolerance requires translocation, sumoylation and binding to WRKY 29. New Phytol. 214, 695705. doi: $10.1111 /$ nph. 14388

Li, Z., and Howell, S. H. (2021). Review: The two faces of IRE1 and their role in protecting plants from stress. Plant Sci. 303:110758. doi: 10.1016/j.plantsci. 2020.110758

Liang, X., Li, S.-W., Gong, L.-M., Li, S., and Zhang, Y. (2020). COPII components Sarlb and Sarlc play distinct yet interchangeable roles in pollen development. Plant Physiol. 183, 974-985. doi: 10.1104/pp.20.00159

Liu, J.-X., and Howell, S. H. (2010). Endoplasmic reticulum protein quality control and its relationship to environmental stress responses in plants. Plant Cell 22, 2930-2942. doi: 10.1105/tpc.110.078154

Lohani, N., Singh, M. B., and Bhalla, P. L. (2020). High temperature susceptibility of sexual reproduction in crop plants. J. Exp. Bot. 71, 555-568. doi: 10.1093/ jxb/erz426

Lohani, N., Singh, M. B., and Bhalla, P. L. (2021). RNA-seq highlights molecular events associated with impaired pollen-pistil interactions following short term heat stress in Brassica napus. Front. Plant Sci. 11:622748. doi: 10.3389/fpls.2020. 622748

Ma, Z.-X., Leng, Y.-J., Chen, G.-X., Zhou, P.-M., Ye, D., and Chen, L.-Q. (2015). The thermosensitive male sterile 1 interacts with the BiPs via DnaJ domain and stimulates their ATPase enzyme activities in Arabidopsis. PLoS One 10:e0132500. doi: 10.1371/journal.pone.0132500

Marshall, R. S., and Vierstra, R. D. (2018). Autophagy: the master of bulk and selective recycling. Ann. Rev. Plant Biol. 69, 173-208. doi: 10.1146/annurevarplant-042817-040606

Martínez, I. M., and Chrispeels, M. J. (2003). Genomic analysis of the unfolded protein response in Arabidopsis shows its connection to important cellular processes. Plant Cell 15, 561-576. doi: 10.1105/tpc.0 07609

Maruyama, D., Endo, T., and Nishikawa, S.-I. (2010). BiP-mediated polar nuclei fusion is essential for the regulation of endosperm nuclei proliferation in Arabidopsis thaliana. Proc. Natl. Acad. Sci. U.S.A. 107, 1684-1689. doi: 10.1073/ pnas.0905795107

Maruyama, D., Sugiyama, T., Endo, T., and Nishikawa, S.-I. (2014). Multiple $\mathrm{BiP}$ genes of Arabidopsis thaliana are required for male gametogenesis and pollen competitiveness. Plant Cell Physiol. 55, 801-810. doi: 10.1093/pcp/ pcu018

Maruyama, D., Endo, T., and Nishikawa, S.-I. (2015). BiP3 supports the early stages of female gametogenesis in the absence of BiP1 and BiP2 in Arabidopsis thaliana. Plant Signal. Behav. 10:e1035853. doi: 10.1080/15592324.2015. 1035853

Mayer, M. P., and Gierasch, L. M. (2019). Recent advances in the structural and mechanistic aspects of Hsp70 molecular chaperones. J. Biol. Chem. 294, 2085-2097. doi: $10.1074 /$ jbc.rev118.002810
Mitterreiter, M. J., Bosch, F. A., Brylok, T., and Schwenkert, S. (2020). The ER luminal C-terminus of AtSec62 is critical for male fertility and plant growth in Arabidopsis thaliana. Plant J. 101, 5-17. doi: 10.1111/tpj. 14483

Nawkar, G. M., Lee, E. S., Shelake, R. M., Park, J. H., Ryu, S. W., Kang, C. H., et al. (2018). Activation of the transducers of unfolded protein response in plants. Front. Plant Sci. 9:214.

Okada, T., Singh, M., and Bhalla, P. L. (2007). Transcriptome profiling of Lilium longiflorum generative cells by cDNA microarray. Plant Cell Rep. 26, 1045-1052. doi: 10.1007/s00299-006-0300-9

Poidevin, L., Forment, J., Unal, D., and Ferrando, A. (2020). Transcriptome and translatome changes in germinated pollen under heat stress uncover roles of transporter genes involved in pollen tube growth. Plant Cell Environ. 34, 61-78. doi: 10.1007/s00497-020-00400-1

Preston, G. M., and Brodsky, J. L. (2017). The evolving role of ubiquitin modification in endoplasmic reticulum-associated degradation. Biochem. J. 474, 445-469. doi: 10.1042/bcj20160582

Qin, Y., Leydon, A. R., Manziello, A., Pandey, R., Mount, D., Denic, S., et al. (2009). Penetration of the stigma and style elicits a novel transcriptome in pollen tubes, pointing to genes critical for growth in a pistil. PLoS Genet. 5:e1000621. doi: 10.1371/journal.pgen.1000621

Reiu, I., Twell, D., and Firon, N. (2017). Pollen development at high temperature: from acclimation to collapse. Plant Physiol. 173, 1967-1976. doi: 10.1104/pp. 16.01644

Reyes, F., León, G., Donoso, M., Brandizzí, F., Weber, A. P., and Orellana, A. (2010). The nucleotide sugar transporters AtUTr1 and AtUTr3 are required for the incorporation of UDP-glucose into the endoplasmic reticulum, are essential for pollen development and are needed for embryo sac progress in Arabidopsis thaliana. Plant J. 61, 423-435. doi: 10.1111/j.1365-313x.2009. 04066.x

Russell, S. D., Gou, X., Wong, C. E., Wang, X., Yuan, T., Wei, X., et al. (2012). Genomic profiling of rice sperm cell transcripts reveals conserved and distinct elements in the flowering plant male germ lineage. New Phytol. 195, 560-573. doi: 10.1111/j.1469-8137.2012.04199.x

Russell, S. D., and Jones, D. S. (2015). The male germline of angiosperms: repertoire of an inconspicuous but important cell lineage. Front. Plant Sci. 6:173.

Russell, S. D., and Strout, G. W. (2005). Microgametogenesis in Plumbago zeylanica (Plumbaginaceae). 2. quantitative cell and organelle dynamics of the male reproductive cell lineage. Sex. Plant Reproduct. 18, 113-130. doi: 10.1007/ s00497-005-0005-1

Schubert, U., Anton, L. C., Gibbs, J., Norbury, C. C., Yewdell, J. W., and Bennink, J. R. (2000). Rapid degradation of a large fraction of newly synthesized proteins by proteasomes. Nature 404, 770-774. doi: 10.1038/35008096

Singh, M. B., and Bhalla, P. L. (2007). Control of male germ-cell development in flowering plants. Bioessays 29, 1124-1132. doi: 10.1002/bies.20660

Singh, M. B., Bhalla, P. L., and Russell, S. D. (2008). Molecular repertoire of flowering plant male germ cells. Sex. Plant Reproduct. 21, 27-36. doi: 10.1007/ s00497-008-0067-y

Sobri, B. M., and Zulfazli, M. (2016). Analysis of Metacaspase-5 Function in Arabidopsis thaliana. Manchester: University of Manchester.

Sugio, A., Dreos, R., Aparicio, F., and Maule, A. J. (2009). The cytosolic protein response as a subcomponent of the wider heat shock response in Arabidopsis. Plant Cell 21, 642-654. doi: 10.1105/tpc.108.062596

Tanaka, Y., Nishimura, K., Kawamukai, M., Oshima, A., and Nakagawa, T. (2013). Redundant function of two Arabidopsis COPII components, AtSec24B and AtSec24C, is essential for male and female gametogenesis. Planta 238, 561-575. doi: 10.1007/s00425-013-1913-1

Vu, K. V., Nguyen, N. T., Jeong, C. Y., Lee, Y. H., Lee, H., and Hong, S. W. (2017). Systematic deletion of the ER lectin chaperone genes reveals their roles in vegetative growth and male gametophyte development in Arabidopsis. Plant J. 89, 972-983. doi: $10.1111 /$ tpj.13435

Wirawan, E., Berghe, T. V., Lippens, S., Agostinis, P., and Vandenabeele, P. (2012). Autophagy: for better or for worse. Cell Res. 22, 43-61.

Xie, H.-T., Wan, Z.-Y., Li, S., and Zhang, Y. (2014). Spatiotemporal production of reactive oxygen species by NADPH oxidase is critical for tapetal programmed cell death and pollen development in Arabidopsis. Plant Cell 26, 2007-2023. doi: $10.1105 /$ tpc.114.125427 
Xu, H., Swoboda, I., Bhalla, P. L., and Singh, M. B. (1999). Male gametic cell-specific gene expression in flowering plants. Proc. Natl. Acad. Sci. U.S.A. 96, 2554-2558. doi: $10.1073 /$ pnas.96.5.2554

Yamamoto, M., Maruyama, D., Endo, T., and Nishikawa, S.-I. (2008). Arabidopsis thaliana has a set of $\mathrm{J}$ proteins in the endoplasmic reticulum that are conserved from yeast to animals and plants. Plant Cell Physiol. 49, 1547-1562. doi: 10. 1093/pcp/pcn119

Yamamoto, M., Uji, S., Sugiyama, T., Sakamoto, T., Kimura, S., Endo, T., et al. (2020). ERdj3B-mediated quality control maintains anther development at high temperatures. Plant Physiol. 182, 1979-1990. doi: 10.1104/pp.19.0 1356

Yang, K. Z., Xia, C., Liu, X. L., Dou, X. Y., Wang, W., Chen, L. Q., et al. (2009). A mutation in Thermosensitive Male Sterile 1, encoding a heat shock protein with DnaJ and PDI domains, leads to thermosensitive gametophytic male sterility in Arabidopsis. Plant J. 57, 870-882. doi: 10.1111/j.1365-313x.2008.0 3732.x

Zhang, D., Liu, D., Lv, X., Wang, Y., Xun, Z., Liu, Z., et al. (2014). The cysteine protease CEP1, a key executor involved in tapetal programmed cell death, regulates pollen development in Arabidopsis. Plant Cell 26, 2939-2961. doi: $10.1105 /$ tpc.114.127282

Zhang, S.-S., Yang, H., Ding, L., Song, Z.-T., Ma, H., Chang, F., et al. (2017). Tissuespecific transcriptomics reveals an important role of the unfolded protein response in maintaining fertility upon heat stress in Arabidopsis. Plant Cell 29, 1007-1023. doi: $10.1105 /$ tpc. 16.00916

Conflict of Interest: The authors declare that the research was conducted in the absence of any commercial or financial relationships that could be construed as a potential conflict of interest.

Copyright (c) 2021 Singh, Lohani and Bhalla. This is an open-access article distributed under the terms of the Creative Commons Attribution License (CC BY). The use, distribution or reproduction in other forums is permitted, provided the original author(s) and the copyright owner(s) are credited and that the original publication in this journal is cited, in accordance with accepted academic practice. No use, distribution or reproduction is permitted which does not comply with these terms. 